\title{
Busseihydroquinones A-D from the Roots of Pentas bussei
}

Milkyas Endale, ${ }^{\dagger, \ddagger}$ Annabel Ekberg, ${ }^{\ddagger}, \S$ Hoseah M. Akala, ${ }^{\perp}$ John Patrick Alao, ${ }^{\ddagger}$ Per Sunnerhagen, ${ }^{\ddagger}$ Abiy Yenesew, ${ }^{* \dagger}$ and Máté Erdélyi*,\$,

${ }^{\dagger}$ Department of Chemistry, University of Nairobi, P.O. Box 30197-00100, Nairobi, Kenya

${ }^{\ddagger}$ Department of Chemistry and Molecular Biology, University of Gothenburg, SE-412 96 Gothenburg, Sweden

${ }^{\S}$ Swedish NMR Centre, University of Gothenburg, P.O. Box 465, SE-40530 Gothenburg, Sweden

${ }^{\perp}$ United States Army Medical Research Unit-Kenya, MRU 64109, APO, AE 09831-4109, United States

Supporting Information

ABSTRACT: Four new naphthohydroquinones, named busseihydroquinones A-D (1-4), along with a known homoprenylated dihydronaphthoquinone (5), were isolated from the $\mathrm{CH}_{2} \mathrm{Cl}_{2} / \mathrm{MeOH}$ (1:1) extract of the roots of Pentas bussei. Although the genus Pentas is frequently used by traditional healers for the treatment of malaria, only marginal activities against the chloroquine-sensitive (D6) and the chloroquineresistant (W2) strains of Plasmodium falciparum were observed for the crude root extract and the isolated constituents of this plant.

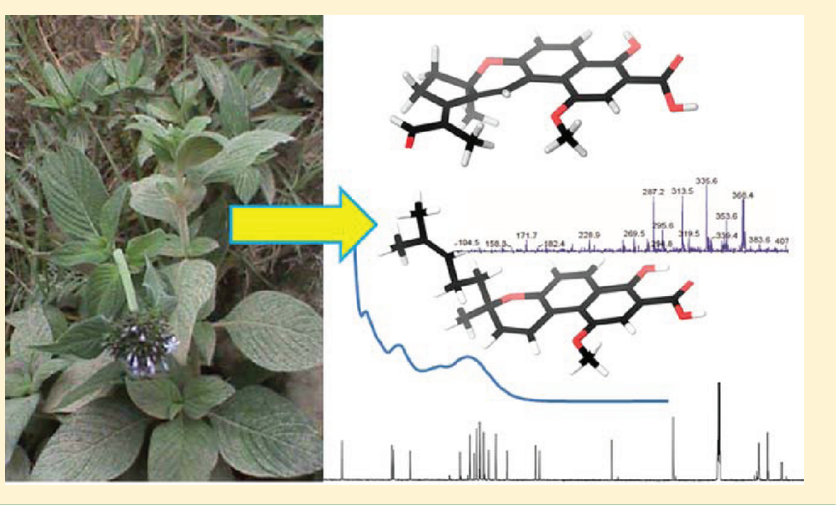

M alaria remains a widespread, potentially fatal parasitic infection causing millions of deaths every year. ${ }^{1}$ Most effective antimalarials are unaffordable to the majority of developing countries, where malaria is prevalent, and the efficacy of these preparations is declining rapidly. ${ }^{2,3}$ As modern techniques, e.g., genomics, high-throughput screening, and target-oriented drug development strategies, have not yet fulfilled the expectations that appeared promising upon their introduction, chemotherapeutics is still the cornerstone of patient management and will likely remain so for the foreseeable future. $^{4-6}$ Rapid resistance development to existing medicines reveals the essential need for drugs with novel modes of action. ${ }^{6}$ Since all first-line antimalarials are natural products or their derivatives, ${ }^{5}$ evaluation of plant-based indigenous medicines still appears as one of the promising sources of novel antiplasmodial leads.

Originating from its traditional use for the treatment of malaria in Africa and Asia, the interest in the genus Pentas has recently increased. ${ }^{7}$ P. longiflora was recognized as a source of quinones, ${ }^{8-11}$ with its pyranonaphthoquinones showing potent antiplasmodial activity. ${ }^{11}$ Antiplasmodial anthraquinones were recently isolated from the roots of $P$. lanceolata. ${ }^{11}$ The use of Pentas bussei for malaria treatment at the Kenyan coast has been reported. ${ }^{12}$ The crude extract of its roots showed moderate activity against Plasmodium strains. ${ }^{13}$ De Kimpe et al. reported the isolation of a novel benzochromene ${ }^{14}$ as well as a naphthohydroquinone ${ }^{15}$ from the roots of this plant without, however, reporting their biological activities. The isolation, spectroscopic identification, and biological evaluation of four additional naphthohydroquinones named here as busseihydro- quinones A-D (compounds 1-4, Figure 1) from the roots of $P$. bussei are reported along with the confirmation of the presence of the previously reported homoprenylated naphthohydroquinone (5). ${ }^{14}$

\section{RESULTS AND DISCUSSION}

Chromatographic separation of the $\mathrm{CH}_{2} \mathrm{Cl}_{2} / \mathrm{MeOH}$ (1:1) root extract of $P$. bussei yielded five compounds, which were characterized by NMR, UV, IR, CD, and MS methods.

Busseihydroquinone A (1). 1 was isolated as needle-like crystals by recrystallization from $\mathrm{MeOH}$. HRMS provided the exact mass of $m / z 309.2300[\mathrm{M}+\mathrm{H}]^{+}$, compatible with the molecular formula $\mathrm{C}_{15} \mathrm{H}_{16} \mathrm{O}_{7}$ (calcd 309.2379). In agreement with $\mathrm{MS}$, the ${ }^{13} \mathrm{C}$ NMR spectrum showed 15 carbon signals consisting of a carbonyl, four methyl, and 10 aromatic carbons (Table 1). ${ }^{1} \mathrm{H}$ NMR data confirmed the presence of four $O$ methyl groups, of which $\mathrm{HMBC}$ and HSQC indicated three methoxy functionalities $\left(\delta_{\mathrm{H}} 3.91,3.90\right.$, and 3.76) and one methyl ester group $\left(\delta_{\mathrm{H}} 3.94\right)$, as well as the presence of two aromatic proton singlets. Using dry DMSO- $d_{6}$ as solvent permitted the identification of two $\left(\delta_{\mathrm{H}} 9.83\right.$ and 12.45) intramolecularly hydrogen-bonded hydroxy groups. The HMBC correlations (Supporting Information) of the aromatic proton at $\delta_{\mathrm{H}} 6.94$ to two oxygenated quaternary carbons $\left({ }^{2} J_{\mathrm{CH}}\right.$ to $\delta_{\mathrm{C}} 146.3$ and ${ }^{3} J_{\mathrm{CH}}$ to $\delta_{\mathrm{C}} 154.6$ ), to two quaternary carbons $\left({ }^{2} J_{\mathrm{CH}}\right.$ to $\delta_{\mathrm{C}} 102.2,{ }^{3} J_{\mathrm{CH}}$ to $\left.\delta_{\mathrm{C}} 127.1\right)$, and to the ester carbonyl

Received: March 22, 2012 
<smiles>COC(=O)c1cc(OC)c2c(O)c(OC)c(OC)cc2c1O</smiles>

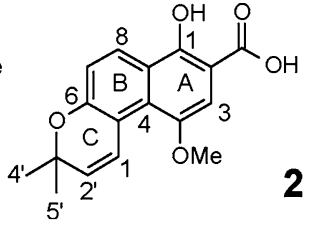

2

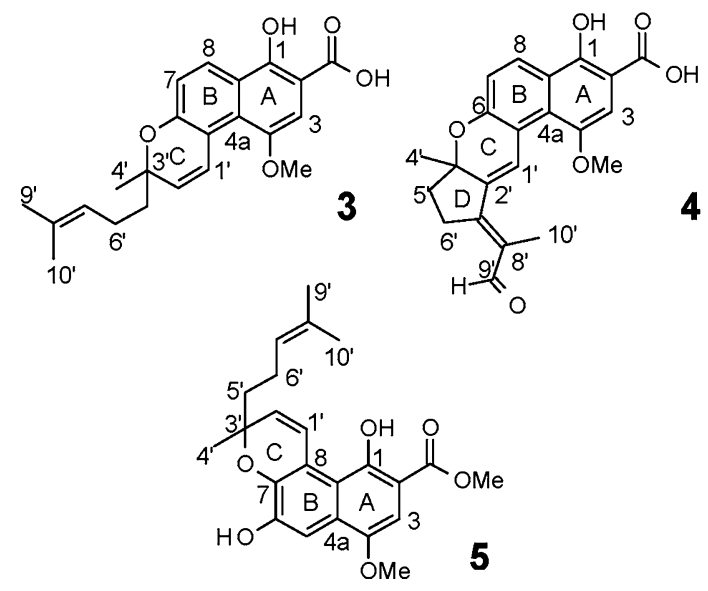

Figure 1. Naphthohydroquinones isolated from the roots of $P$. bussei. The racemic nature of compounds 3-5 was revealed by their lack of optical rotation.

carbon $\left({ }^{3} J_{\mathrm{CH}}\right.$ to $\left.\delta_{\mathrm{C}} 170.4\right)$ and a further weak correlation to an additional quaternary carbon $\left({ }^{4} J_{\mathrm{CH}}\right.$ to $\left.\delta_{\mathrm{C}} 109.9\right)$ allowed its assignment as $\mathrm{H}-3$ of ring $\mathrm{A}$. HMBC data revealed that $\mathrm{C}-4$ of this ring is methoxy substituted $\left({ }^{3} J_{\mathrm{CH}} \delta_{\mathrm{H}} 3.90\right.$ to $\left.\delta_{\mathrm{C}} 146.3\right)$, whereas $\mathrm{C}-1$ is hydroxylated. A further weak $\mathrm{HMBC}$ correlation of $\delta_{\mathrm{H}} 6.94$ to $\delta_{\mathrm{C}} 93.5$, originating from a ${ }^{4} J_{\mathrm{CH}} W$-coupling, pointed to the $\mathrm{B}$ ring and defined the position of its $\mathrm{H}-5$ (HSQC cross-peak of $\delta_{\mathrm{H}} 7.05$ to $\delta_{\mathrm{C}} 93.5$ ). HMBC correlations of this proton defined the positions of two methoxy $\left({ }^{2} J_{\mathrm{CH}}\right.$ to $\delta_{\mathrm{C}} 155.5,{ }^{3} J_{\mathrm{CH}}$ to $\delta_{\mathrm{C}} 134.9$ ) and hydroxy groups (weak ${ }^{4} J_{\mathrm{CH}}$ to $\left.\delta_{\mathrm{C}} 148.8\right)$ in addition to confirming its relative position to the bridging carbons $\left({ }^{2} J_{\mathrm{CH}}\right.$ to $\delta_{\mathrm{C}} 127.1,{ }^{3} J_{\mathrm{CH}}$ to $\left.\delta_{\mathrm{C}} 109.9\right)$ of the naphthalene backbone. The ${ }^{3} J_{\mathrm{CH}} \mathrm{HMBC}$ correlation of $\delta_{\mathrm{H}} 7.05$ to $\delta_{\mathrm{C}} 146.3$ confirmed its peri position to C-4. The deshielded methoxy signal $\left(\delta_{\mathrm{C}} 60.1\right)$ bound to shielded C-7 was indicative of being both ortho to a hydroxy at C-8 and ortho to a methoxy at C-6. ${ }^{16}$ NOESY cross-peaks (Supporting Information) between $\mathrm{H}-3$ and $4-\mathrm{OCH}_{3}$ as well as $\mathrm{H}-5$ and $6-\mathrm{OCH}_{3}$ further confirmed the position of the aromatic protons and the two methoxy groups. In the MS spectrum of 1 the vicinal position of the C-1 hydroxy group and the ester carbonyl was indicated by expulsion of $\mathrm{MeOH}\left([\mathrm{M}+1]^{+}-32\right)$, resulting in the base peak, by formation of the corresponding characteristic ketene ion ("ortho effect"). The new compound was therefore characterized as methyl 1,8-dihydroxy-4,6,7-trimethoxynaphthalene-2-carboxylate (Figure 1) and was given the trivial name busseihydroquinone A.

Busseihydroquinone B (2). 2 was isolated as a powder and showed a molecular ion peak of $m / z 299.0919[\mathrm{M}-\mathrm{H}]^{-}$, consistent with the molecular formula $\mathrm{C}_{17} \mathrm{H}_{16} \mathrm{O}_{5}$ (calcd

Table 1. ${ }^{1} \mathrm{H}$ and ${ }^{13} \mathrm{C}$ NMR of Compounds $1-5\left(\mathrm{DMSO}-d_{6}, 25^{\circ} \mathrm{C}\right)^{a}$

\begin{tabular}{|c|c|c|c|c|c|c|c|c|c|c|}
\hline \multirow[b]{2}{*}{ position } & \multicolumn{2}{|c|}{1} & \multicolumn{2}{|c|}{2} & \multicolumn{2}{|c|}{3} & \multicolumn{2}{|c|}{4} & \multicolumn{2}{|c|}{5} \\
\hline & $\delta_{\mathrm{H}}$ & $\overline{\delta_{\mathrm{C}}}$ & $\delta_{\mathrm{H}}(J$ in $\mathrm{Hz})$ & $\overline{\delta_{\mathrm{C}}}$ & $\delta_{\mathrm{H}}(J$ in $\mathrm{Hz})$ & $\delta_{\mathrm{C}}$ & $\delta_{\mathrm{H}}(J$ in $\mathrm{Hz})$ & $\delta_{\mathrm{C}}$ & $\delta_{\mathrm{H}}(J$ in $\mathrm{Hz})$ & $\overline{\delta_{\mathrm{C}}}$ \\
\hline 1 & & 154.6, C & & 154.9, C & & 155.0, C & & 154.9, C & & 156.4, C \\
\hline 2 & & 102.2, C & & 103.0, C & & 102.9, C & & $105.4, \mathrm{C}$ & & 102.6, C \\
\hline 3 & $6.94, \mathrm{~s}$ & $100.4, \mathrm{CH}$ & $7.07, \mathrm{~s}$ & 104.2, CH & $7.06, \mathrm{~s}$ & $104.3, \mathrm{CH}$ & $7.10, \mathrm{~s}$ & 103.9, CH & $6.88, \mathrm{~s}$ & $98.8, \mathrm{CH}$ \\
\hline 4 & & 146.3, C & & $148.5, \mathrm{C}$ & & 148.5, C & & 148.2, C & & 146.0, C \\
\hline $4 a$ & & 127.1, C & & $125.9, \mathrm{C}$ & & $125.9, \mathrm{C}$ & & $126.4, \mathrm{C}$ & & 126.2, C \\
\hline 5 & $7.05, \mathrm{~s}$ & 93.5, CH & & $114.4, \mathrm{C}$ & & 114.3, C & & 115.6, C & $7.41, \mathrm{~s}$ & $105.4, \mathrm{CH}$ \\
\hline 6 & & 155.5, C & & $154.2, \mathrm{C}$ & & $154.4, \mathrm{C}$ & & $154.3, \mathrm{C}$ & & 149.2, C \\
\hline 7 & & 134.9, C & $7.13, \mathrm{~d}(8.2)$ & $118.3, \mathrm{CH}$ & $7.10, \mathrm{~d}(8.7)$ & $118.2, \mathrm{CH}$ & $7.21, \mathrm{~d}(9.1)$ & $118.1, \mathrm{CH}$ & & $142.5, \mathrm{C}$ \\
\hline 8 & & $148.8, \mathrm{C}$ & $8.12, \mathrm{~d}(8.2)$ & $125.0, \mathrm{CH}$ & $8.11, \mathrm{~d}(8.7)$ & $124.8, \mathrm{CH}$ & $8.22, \mathrm{~d}(9.1)$ & $126.9, \mathrm{CH}$ & & $117.5, \mathrm{C}$ \\
\hline $8 \mathrm{a}$ & & 109.9, C & & $120.8, \mathrm{C}$ & & $120.8, \mathrm{C}$ & & 121.2, C & & $114.5, \mathrm{C}$ \\
\hline $1^{\prime}$ & & & $7.63, \mathrm{~d}(9.2)$ & 122.1, CH & $7.70, \mathrm{~d}(10.4)$ & $122.5, \mathrm{CH}$ & $8.27, \mathrm{~s}$ & $126.5, \mathrm{CH}$ & $7.83, \mathrm{~d}(10.3)$ & $122.6, \mathrm{CH}$ \\
\hline $2^{\prime}$ & & & $5.71, \mathrm{~d}(9.2)$ & $128.2, \mathrm{CH}$ & $5.68, \mathrm{~d}(10.4)$ & $127.3, \mathrm{CH}$ & & 137.3, C & $5.76, \mathrm{~d}(10.3)$ & $128.4, \mathrm{CH}$ \\
\hline $3^{\prime}$ & & & & 75.1, C & & $77.4, \mathrm{C}$ & & $82.0, \mathrm{C}$ & & 77.0, C \\
\hline $4^{\prime}$ & & & $1.44, \mathrm{~s}$ & 27.0, $\mathrm{CH}_{3}$ & $1.37, \mathrm{~s}$ & $25.4, \mathrm{CH}_{3}$ & $1.32, \mathrm{~s}$ & 21.1, $\mathrm{CH}_{3}$ & $1.39, \mathrm{~s}$ & $24.9, \mathrm{CH}_{3}$ \\
\hline $5^{\prime}$ & & & & & $1.67, \mathrm{~m}$ & $39.9, \mathrm{CH}_{2}$ & $2.18,2.30, \mathrm{~m}$ & 37.2, $\mathrm{CH}_{2}$ & $1.70, \mathrm{~m}$ & $39.9 \mathrm{CH}_{2}$ \\
\hline $6^{\prime}$ & & & & & $2.05, \mathrm{~m}$ & 22.2, $\mathrm{CH}_{2}$ & $2.88,3.39, \mathrm{~m}$ & 25.6, $\mathrm{CH}_{2}$ & $2.08, \mathrm{~m}$ & $22.2 \mathrm{CH}_{2}$ \\
\hline $7^{\prime}$ & & & & & $5.05, \mathrm{t}(6.8)$ & $123.9, \mathrm{CH}$ & & $152.6, \mathrm{C}$ & $5.08, \mathrm{t}(6.8)$ & $124.0 \mathrm{CH}$ \\
\hline $8^{\prime}$ & & & & & & $130.9, \mathrm{C}$ & & 130.0, C & & $130.9, \mathrm{C}$ \\
\hline $9^{\prime}$ & & & & & $1.49, \mathrm{~s}$ & $17.4, \mathrm{CH}_{3}$ & $10.0, \mathrm{~s}$ & $191.8, \mathrm{CH}$ & $1.51, \mathrm{~s}$ & $17.4, \mathrm{CH}_{3}$ \\
\hline $10^{\prime}$ & & & & & $1.59, \mathrm{~s}$ & 25.3, $\mathrm{CH}_{3}$ & $2.05, \mathrm{~s}$ & $11.8, \mathrm{CH}_{3}$ & $1.60, \mathrm{~s}$ & $25.4, \mathrm{CH}_{3}$ \\
\hline 4-OMe & $3.90, \mathrm{~s}$ & $55.6, \mathrm{CH}_{3}$ & $3.86, \mathrm{~s}$ & $55.6, \mathrm{CH}_{3}$ & $3.85, \mathrm{~s}$ & $55.7, \mathrm{CH}_{3}$ & $3.89, \mathrm{~s}$ & $56.0, \mathrm{CH}_{3}$ & $3.86, \mathrm{~s}$ & $55.5, \mathrm{CH}_{3}$ \\
\hline $\begin{array}{c}\text { 6-OMe/ } \\
\mathrm{OH}\end{array}$ & $3.91, \mathrm{~s}$ & $55.7, \mathrm{CH}_{3}$ & & & & & & & 9.96 , br s & \\
\hline 7-OMe & $3.76, \mathrm{~s}$ & $60.1, \mathrm{CH}_{3}$ & & & & & & & & \\
\hline $8-\mathrm{OH}$ & 9.83 , br s & & & & & & & & & \\
\hline $1-\mathrm{OH}$ & $\begin{array}{r}12.45 \\
\text { br } s\end{array}$ & & 12.40 , br s & & 12.20 , br s & & 12.40 , br s & & 12.29, br s & \\
\hline 2-ㅡOOMe & & $170.4, \mathrm{C}$ & & $172.5, \mathrm{C}$ & & 172.6, C & & $172.3, \mathrm{C}$ & & $171.5, \mathrm{C}$ \\
\hline 2-COOMe & $3.94, \mathrm{~s}$ & $52.6, \mathrm{CH}_{3}$ & & & & & & & $3.94, s$ & $52.5, \mathrm{CH}_{3}$ \\
\hline
\end{tabular}

${ }^{a}$ NMR spectra, including assigned HMBC and NOE correlations, are shown in the Supporting Information. 
299.0953). Its COSY spectrum (Supporting Information) revealed two independent pairs of aromatic or vinylic protons vicinal to each other as well as the presence of a noncoupled aromatic proton and a methoxy group. The HMBC spectrum revealed a substituted naphthalene skeleton with a comparable substitution pattern of its $\mathrm{A}$ ring, indicated by similar chemical shifts for C-1-C-4 to those of compound 1 (Figure 1, Table 1). NOE cross-peaks between $\mathrm{H}-3$ and $4-\mathrm{OCH}_{3}$ as well as $\mathrm{H}-1^{\prime}$ and 4- $\mathrm{OCH}_{3}$ revealed the annulation of ring $\mathrm{C}$ (2,2-dimethylpyran) to ring $\mathrm{B}$, forming a $3 H$-benzo $[f]$ chromene skeleton. The NOESY and HMBC data (Supporting Information) allowed unambiguous assignment of all functionalities, including determination of the position of the dimethyl substituents of the $\mathrm{C}$ ring. Hence, 2 was identified as the new 1-hydroxy-4methoxy-3', $3^{\prime}$-dimethyl-3H-benzo $[f]$ chromene-2-carboxylic acid and was given the trivial name busseihydroquinone $\mathrm{B}$. It should be noted that 2 is isomeric to mollugin, ${ }^{17}$ a natural product isolated from Pentas longiflora ${ }^{11}$ and synthetically extensively explored by De Kimpe et al. ${ }^{18-21}$

Busseihydroquinone C (3). 3 was isolated as an amorphous solid and was observed to have the exact mass $m / z 368.1418[\mathrm{M}-\mathrm{H}]^{-}$, attributable to the molecular formula $\mathrm{C}_{22} \mathrm{H}_{23} \mathrm{O}_{5}$ (calcd 368.1460). Its ${ }^{1} \mathrm{H}$ and ${ }^{13} \mathrm{C}$ NMR shifts (Table 1 and Figures S16 and S17) indicated a $3 H$-benzo $[f]$ chromene skeleton comparable to that of compound 2 . The close similarity of the chemical shifts of atoms 1-8 suggested identical substitution patterns for rings $\mathrm{A}$ and $\mathrm{B}$ for $\mathbf{2}$ and 3, which was confirmed by HSQC/HMBC analysis. The annulation of the benzochromene ring (Figure 1) was confirmed by ${ }^{3} J_{\mathrm{CH}} \mathrm{HMBC}$ magnetization transfers (Supporting Information) between $\mathrm{H}-8$ and $\mathrm{C}-4 \mathrm{a}, \mathrm{H}-\mathrm{1}^{\prime}$ and $\mathrm{C}-4 \mathrm{a}, \mathrm{H}-7$ and $\mathrm{C}-5$, and $\mathrm{H}-2^{\prime}$ and $\mathrm{C}-5$. A further confirmation was provided by the NOESY cross-peaks of $4-\mathrm{OCH}_{3}$ to $\mathrm{H}-3$ and $\mathrm{H}-1^{\prime}$, whereas no NOE transfer between $4-\mathrm{OCH}_{3}$ and $\mathrm{H}-8$ (Figure 2) was

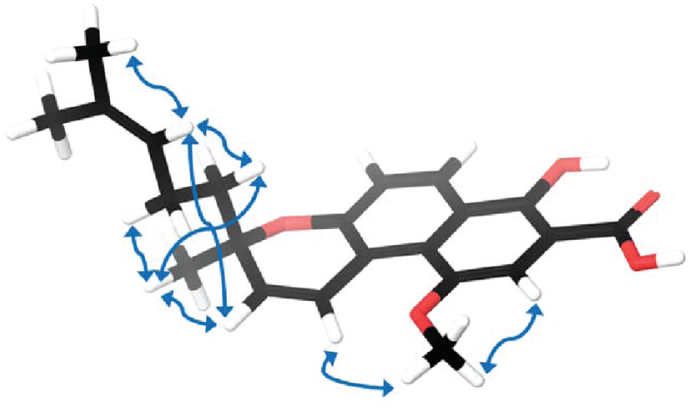

Figure 2. Key NOE correlations observed for compound 3 (mixing time $700 \mathrm{~ms}$, DMSO- $d_{6}, 25{ }^{\circ} \mathrm{C}, 800 \mathrm{MHz}$, Supporting Information).

observed. Similar to $\mathbf{2}$, cyclization of a geranyl substituent at C5 resulted in formation of the pyran ring of 3 , revealed by the mutually coupled doublets at $\delta_{\mathrm{H}} 7.70$ and 5.68 and the quaternary carbon at $\delta_{\mathrm{C}}$ 77.3. $\mathrm{HMBC}$ correlations along with the NOE data (Figure 2) indicated a methyl and a 4methylpent-3-enyl substituent at C-3' of the pyran ring. By combination of the above spectroscopic evidence, the third new compound was identified as rac-1-hydroxy-4-methoxy-3'methyl-3'-(4-methylpent-3-enyl)-3H-benzo $[f]$ chromene-2-carboxylic acid (3) and was given the trivial name busseihydroquinone $\mathrm{C}$.

Busseihydroquinone D (4). 4 was isolated as an amorphous solid with exact molecular mass (HRMS) $\mathrm{m} / \mathrm{z}$
379.1182, attributed to $\mathrm{C}_{22} \mathrm{H}_{20} \mathrm{O}_{6}$ (calcd for $[\mathrm{M}-\mathrm{H}]^{-}$ 379.1176). The NMR chemical shifts (Table 1) indicated a $3 H$-benzo $[f]$ chromene backbone similar to compounds 2 and 3 , with a hydroxy $\left(\delta_{\mathrm{H}} 12.40\right)$ at $\mathrm{C}-1$, a carboxylic $\left(\delta_{\mathrm{C}} 172.6\right)$ at $\mathrm{C}-2$, and a methoxy $\left(\delta_{\mathrm{H}} 3.89, \delta_{\mathrm{C}} 56.0\right)$ substituent at C-4 in ring $\mathrm{A}$, derived by HMBC data (Supporting Information). The presence of a pair of ortho-coupled protons $\left(\delta_{\mathrm{H}} 7.21\right.$ and 8.22, ${ }^{3} J=9.1 \mathrm{~Hz}$ ) indicated disubstitution in ring $\mathrm{B}$. HMBC correlation of the doublet at $\delta_{\mathrm{H}} 8.22$ with $\delta_{\mathrm{C}} 154.9(\mathrm{C}-1)$ allowed its assignment to $\mathrm{H}-8$, peri to the $\mathrm{C}-1$ hydroxy group. The HMBC cross-peaks of $\mathrm{H}-8\left(\delta_{\mathrm{H}} 8.22\right)$ to C-6 $\left(\delta_{\mathrm{C}} 154.3\right)$ and $\mathrm{C}-4 \mathrm{a}\left(\delta_{\mathrm{C}} 126.4\right)$ along with the NOE between $4-\mathrm{OCH}_{3}$ and $\mathrm{H}-1$ ' (Figure 3) further confirmed the syn-annulation of ring $\mathrm{B}$

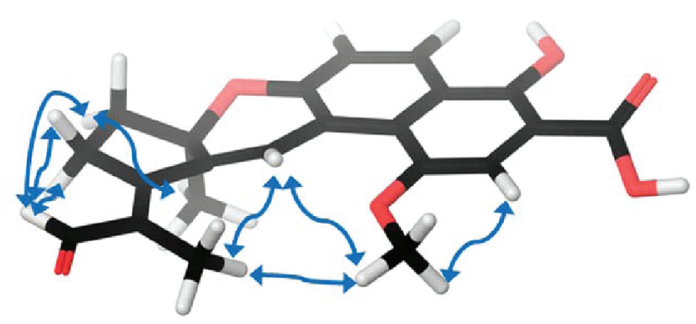

Figure 3. Key NOE correlations observed for compound 4 (mixing time $700 \mathrm{~ms}$, DMSO- $d_{6}, 25^{\circ} \mathrm{C}, 800 \mathrm{MHz}$, Supporting Information).

to $\mathrm{C}$. The presence of a chromene ring was indicated by a singlet at $\delta_{\mathrm{H}} 8.27\left(\mathrm{H}-1^{\prime}\right)$ showing a HMBC correlation to C-4a $\left(\delta_{\mathrm{C}} 126.4\right), \mathrm{C}-5\left(\delta_{\mathrm{C}} 115.6\right)$, and $\mathrm{C}-6\left(\delta_{\mathrm{C}} 154.3\right)$ of ring B as well as with C-3' $\left(\delta_{\mathrm{C}} 82.0\right)$ and the quaternary $\mathrm{sp}^{2}$-hybridized carbon $\mathrm{C}-2^{\prime}$ at $\delta_{\mathrm{C}}$ 137.3. The multiplicity of $\mathrm{H}-1^{\prime}\left(\delta_{\mathrm{H}} 8.27, \mathrm{~s}\right)$ and the HMBC cross-peak pattern of the aliphatic signals 4 '$\mathrm{CH}_{3}, 5^{\prime}-\mathrm{CH}_{2}$, and $6^{\prime}-\mathrm{CH}_{2}$ revealed the presence of a methyl $\left(\mathrm{CH}_{3}-4^{\prime}\right)$ and a pentacyclic ring attached to ring $\mathrm{C}$. In ring $\mathrm{D}$, the COSY spectrum indicates two mutually coupled methylene groups at $\delta_{\mathrm{H}} 2.30$ and $2.18\left(\delta_{\mathrm{C}} 37.2\right)$ and 2.88 and $3.39\left(\delta_{\mathrm{C}}\right.$ 25.6) assignable to $5^{\prime}-\mathrm{CH}_{2}$ and $6^{\prime}-\mathrm{CH}_{2}$, respectively. The 1methyl-2-oxoethylidene substituent attached to $\mathrm{C}-7^{\prime}$ is indicated by $\mathrm{HMBC}$ correlations of $10^{\prime}-\mathrm{CH}_{3}\left(\delta_{\mathrm{H}} 2.05\right)$ to the carbonyl C-9' $\left(\delta_{\mathrm{C}} 191.8\right)$, the quaternary C-8 $8^{\prime}\left(\delta_{\mathrm{C}} 130.0\right)$, and $\mathrm{C}-7^{\prime}\left(\delta_{\mathrm{C}} 152.6\right)$, to which also $5^{\prime}-\mathrm{CH}_{2}$ and $6^{\prime}-\mathrm{CH}_{2}$ showed HMBC correlations. Further confirmation was provided by the HMBC correlations of the $\mathrm{H}-9^{\prime}$ aldehydic proton $\left(\delta_{\mathrm{H}} 10.0\right)$ to C-8' $\left(\delta_{\mathrm{C}} 130.0\right)$ and $\mathrm{CH}_{3}-10^{\prime}\left(\delta_{\mathrm{C}} 11.8\right)$. NOEs observed between $\mathrm{H}-9^{\prime}$ and $6^{\prime}-\mathrm{CH}_{2}$ as well as between $\mathrm{CH}_{3}-10^{\prime}$ and $\mathrm{H}-1^{\prime}$ revealed the E-geometry of the $\mathrm{C}^{\prime}=\mathrm{C}^{\prime}$ bond. The new compound was characterized as $\mathrm{rac}-\left(7^{\prime} E\right)$-1-hydroxy-4-methoxy-3'a-methyl-2'-[1-methyl-2-oxoethylidene]-7a,8,1',2'-tetrahydro-7-oxa-cyclopenta $[b]$ phenanthrene-2-carboxylic acid (4) and given the trivial name busseihydroquinone $\mathrm{D}$.

Spectroscopic analysis (Supporting Information) of compound 5 (HRMS $m / z 399.2020[\mathrm{M}+\mathrm{H}]^{+}$, calcd for $\mathrm{C}_{23} \mathrm{H}_{26} \mathrm{O}_{6}$ 399.1808 ) confirmed the presence of $r a c$-methyl-1,6-dihydroxy4-methoxy-3'-methyl-3'-[4-methyl-3-pentenyl]-3H-benzo[f]chromene-2-carboxylate in the roots of $P$. bussei, as previously reported De Kimpe et al. ${ }^{14}$ The annulation of 5 , which is different from that of 2-4, was confirmed by NOEs observed between $\mathrm{H}-5$ and $\mathrm{OMe}-4$ and between $\mathrm{H}-1^{\prime}$ and $\mathrm{OH}-1$, as shown in Figure 4. Detailed spectroscopic data are given in the Supporting Information. The circular dichroism spectra of compounds 3-5 did not show any observable Cotton effects in the 250-600 nm region; neither was significant optical rotation observed (Experimental Section). These indicated that 
$c$

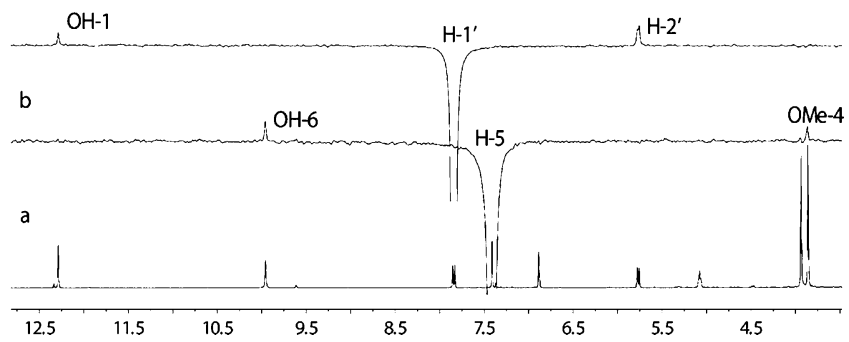

Figure 4. NOE correlations observed for compound 5 indicative of its mode of annulation. (a) Reference spectrum; (b) NOESY1D spectrum, H-5 irradiated; (c) NOESY 1D spectrum, H-1' irradiated. Spectra were obtained in DMSO- $d_{6}$ solution at $25^{\circ} \mathrm{C}$ and $500.30 \mathrm{MHz}$ using a mixing time of $700 \mathrm{~ms}$ and relaxation delay of $2.5 \mathrm{~s}$.

compounds 3-5 occur as racemic mixtures in the analyzed plant sample. For 5, a +34.8 specific rotation was previously reported, ${ }^{14}$ which we are unable to confirm here.

Five natural products possessing the $3 H$-benzo $[f]$ chromene heterocyclic system were isolated. In compounds 2-4 the bridging atoms of rings $\mathrm{B}$ and $\mathrm{C}$ are $\mathrm{C}-5$ and $\mathrm{C}-6$, whereas in compound 5 C-7 and C-8, as was confirmed by HMBC and NOESY spectra. The heterocyclic system of $\mathbf{2 - 5}$ has not been reported from any other organism, and thus further investigation of the genus Pentas is likely to provide more novel natural products.

Biological Activity. The crude extract and all isolated compounds have been examined in vitro for their antiplasmodial activity against the D6 and W2 strains of Plasmodium falciparum (Table 2). Despite the traditional use of the roots of the plant for malaria, our findings revealed that the compounds showed only marginal activity $\left(\mathrm{IC}_{50} 19-36 \mu \mathrm{M}\right)$ against the D6 strain with little cytotoxicity (MCF-7 human breast cancer cells, see Experimental Section), while the crude extract was found to be inactive $\left(\mathrm{IC}_{50} 49-50 \mu \mathrm{g} / \mathrm{mL}\right)$. As the use of $P$. bussei for the treatment of bacterial diseases has also been reported, ${ }^{14,22}$ compounds 1-5 have been investigated for antifungal and antibacterial activities. However, none of them showed significant inhibition of Aspergillus niger, Escherichia coli, Candida albicans, or Staphylococcus aureus, in agar diffusion assays.

Phytochemical investigation of $P$. bussei resulted in the isolation of four new natural products. The plant has previously been studied by De Kimpe and co-workers, ${ }^{14,15}$ but only two compounds had been identified, of which the presence of one is confirmed in this study. Anthraquinones and pyranonaphtho- quinones have been reported from the roots of previously evaluated plants of the genus, such as $P$. lanceolata and $P$. longiflora. ${ }^{11}$ Despite the indigenous use of the genus Pentas including $P$. bussei against malaria and bacterial infections, ${ }^{14,22}$ in our hands neither the crude root extract nor the isolated compounds showed significant antiplasmodial, antibacterial, or antifungal activities, in contrast to the anthraquinones and naphthalene derivatives isolated from two other Pentas species. ${ }^{11}$ This observation reveals the urgent need for thorough scientific evaluation of indigenous medicines to distinguish myths from helpful practices.

\section{EXPERIMENTAL SECTION}

General Experimental Procedures. Optical rotations were measured using a Perkin-Elmer 341 LC polarimeter. IR spectra $(\mathrm{KBr}$ disks) were recorded on a Perkin-Elmer 1725 FTIR spectrometer. NMR analysis was carried out on Varian Unity Inova 500,600 , or $800 \mathrm{MHz}$ spectrometers. Structural assignment was performed on the basis of gCOSY, ${ }^{23}$ gNOESY, ${ }^{24}$ gHSQC, ${ }^{25}$ and gHMBC $^{26}$ spectra. ESIMS was performed on a Perkin-Elmer PE SCIEX API 150 EX instrument equipped with a Turbolon Ionspray source and a Gemini $5 \mathrm{~mm} \mathrm{C} 18110 \AA$ APLC column using a $\mathrm{H}_{2} \mathrm{O}$ / $\mathrm{CH}_{3} \mathrm{CN}$ gradient (80:20 to 20:80). High-resolution mass spectrometric analysis (Q-TOF-MS) was performed at Stenhagen Analyslab $\mathrm{AB}$, Gothenburg, Sweden. Analytical HPLC was run on a HewlettPackard Series 1050 HPLC using the software Chromulan (Pikron Ltd.), a Gemini 5 mm C18 $110 \AA$ HPLC column, and $\mathrm{MeOH} / \mathrm{H}_{2} \mathrm{O}$ eluent mixtures. Column chromatography was performed on oxalic acid-impregnated silica gel [the silica gel was deactivated by mixing 2 $\mathrm{kg}$ of silica gel 60 (70-230 mesh) with $3 \%$ oxalic acid (30 g in $1 \mathrm{~L}$ of $\mathrm{H}_{2} \mathrm{O}$ ) and allowed to stand for $30 \mathrm{~min}$, filtered, and dried in an oven $\left(100{ }^{\circ} \mathrm{C}\right)$ for $\left.45 \mathrm{~min}\right]$. TLC was done using silica gel $60 \mathrm{~F} 254$. An Inotech cell "Harvester 96" on glass fiber filter mats was used to evaluate the bioassays. $\left[\mathrm{G}^{3} \mathrm{H}\right]$ hypoxanthine uptake was determined using the MicroBeta TriLux liquid scintillation and luminescence counter.

Plant Material. The root of Pentas bussei was collected from Mombasa, coastal region of Kenya, on July 14, 2010. The plant material was identified by Mr. Patrick Chalo Motiso, School of Biological Sciences, University of Nairobi, where a voucher specimen under voucher number MEA 2010/003 (P. bussei) is deposited.

Extraction and Isolation. The ground roots of $P$. bussei $(1.1 \mathrm{~kg})$ were extracted by cold percolation with $\mathrm{CH}_{2} \mathrm{Cl}_{2} / \mathrm{MeOH}(1: 1)$ three times for $24 \mathrm{~h}$ in each case. The marc was then extracted with $\mathrm{MeOH}$ as above. The extract was concentrated using a rotary evaporator to yield a brownish crude extract $(63 \mathrm{~g}, 5.72 \%)$. A $61 \mathrm{~g}$ portion of the $\mathrm{CH}_{2} \mathrm{Cl}_{2}: \mathrm{MeOH}$ (1:1) crude extract was subjected to column chromatography (CC, $80 \mathrm{~cm}$ length and $80 \mathrm{~mm}$ diameter, $400 \mathrm{~g}$ of oxalic acid-impregnated silica gel) with an increasing gradient of EtOAc in $n$-hexane. A total of 250 fractions (each ca. $150 \mathrm{~mL}$ ) were collected. Fractions $15-20$ (2\% EtOAc in $n$-hexane) were combined

Table 2. In Vitro Antiplasmodial Activity and Cytotoxicity of Crude Extract and Isolated Compounds of Pentas bussei

\begin{tabular}{|c|c|c|c|c|c|}
\hline \multirow[b]{2}{*}{ sample } & \multicolumn{2}{|c|}{ antiplasmodial activity ${ }^{a}$} & \multirow[b]{2}{*}{$\mathrm{LD}_{50}^{b}(\mu \mathrm{M})$} & \multicolumn{2}{|c|}{$\mathrm{SI}^{c}$} \\
\hline & D6 clone & W2 clone & & $\overline{\text { D6 }}$ & W2 \\
\hline root extract & $49.04 \pm 8.73$ & $49.86 \pm 0.00$ & & & \\
\hline 1 & 36.03 & 144.43 & 304.13 & 8.44 & 2.11 \\
\hline 2 & 27.82 & 126.36 & 373.54 & 13.43 & 2.96 \\
\hline 3 & 32.65 & 60.08 & $>271.62$ & $>8.32$ & $>4.52$ \\
\hline 4 & 19.59 & 80.10 & $>262.07$ & $>13.43$ & $>3.27$ \\
\hline 5 & 30.56 & 85.04 & 86.39 & 2.83 & 1.02 \\
\hline chloroquine & 0.0094 & 0.0063 & & & \\
\hline mefloquine & 0.029 & 0.034 & & & \\
\hline
\end{tabular}

${ }^{a} \mathrm{IC}_{50}$ is given in $\mu \mathrm{g} / \mathrm{mL}$ for crude and in $\mu \mathrm{M}$ for pure compounds. ${ }^{b} \mathrm{LD}_{50}$ : cytotoxicity. ${ }^{c} \mathrm{SI}$ : selectivity index. These values are the mean value of at least $3\left(\mathrm{IC}_{50}\right)$ or at least $6\left(\mathrm{LD}_{50}\right)$ independent experiments. Details are given in the Supporting Information. 
and purified on Sephadex LH-20 (eluent: $\mathrm{CH}_{2} \mathrm{Cl}_{2} / \mathrm{MeOH}, 1: 1$ ) to give compound 5 (30 mg, yellow solid). Fractions 63 and 64 (7\% EtOAc in $n$-hexane) were combined and purified by CC (eluent: increasing gradient of EtOAc in $n$-hexane) to give busseihydroquinone A (1, 20 mg, brown crystals). Fractions $75-79$ (10\% EtOAc in $n$-hexane) were combined and purified by CC (eluent: increasing gradient of EtOAc in $n$-hexane) to give busseihydroquinone $\mathrm{D}(4,25 \mathrm{mg}$, orange solid). Fractions $115-118$ (15\% EtOAc in $n$-hexane) were combined and purified on Sephadex LH-20 to give busseihydroquinone B $(2,30 \mathrm{mg}$, orange powder). Fractions $131-135$ (20\% EtOAc in $n$-hexane) were combined and purified using CC (eluent: increasing gradient of EtOAc in $n$-hexane) to give busseihydroquinone $\mathrm{C}(3,15 \mathrm{mg}$, red solid). The $\mathrm{MeOH}$ extract $(70 \mathrm{~g})$ was subjected to $\mathrm{CC}$ (eluent: increasing gradient of $\mathrm{MeOH}$ in $\mathrm{CH}_{2} \mathrm{Cl}_{2}$ ). A total of 100 fractions (each ca. $150 \mathrm{~mL}$ ) were collected. Busseihydroquinones A (1, $20 \mathrm{mg}$, brown crystals) and B (2, $40 \mathrm{mg}$, yellow powder) and compound 5 (15 mg, yellow solid) were reisolated. Compound purity was determined by NMR and HPLC.

Busseihydroquinone $A(1)$ : brown crystals $(\mathrm{MeOH}), \mathrm{mp} 171.5^{\circ} \mathrm{C}$; $\mathrm{UV}(\mathrm{MeOH}) \lambda_{\max } 285,250 \mathrm{~nm}$; IR $(\mathrm{KBr}) \nu_{\max } 3412,1637,1618$, 1522, $1400 \mathrm{~cm}^{-1}$; ${ }^{1} \mathrm{H}$ and ${ }^{13} \mathrm{C}$ NMR data see Table 1; HRESIMS $\mathrm{m} / z$ $309.2300[\mathrm{M}+\mathrm{H}]^{+}\left(\right.$calcd $\left.\mathrm{C}_{15} \mathrm{H}_{16} \mathrm{O}_{7}, 309.2379\right)$; ESIMS $m / z 309.5$ $[\mathrm{M}+\mathrm{H}]^{+}, 277.1[\mathrm{M}+\mathrm{H}]^{+}-\mathrm{MeOH}$.

Busseihydroquinone $B$ (2): orange powder; $\mathrm{UV}(\mathrm{MeOH}) \lambda_{\max } 280$, 265, $230 \mathrm{~nm}$; IR $(\mathrm{KBr}) \nu_{\max } 3547,3415,1637,1618,1522,1399 \mathrm{~cm}^{-1}$; ${ }^{1} \mathrm{H}$ and ${ }^{13} \mathrm{C}$ NMR data see Table 1; HRESIMS $m / z 299.0919$ [M $\mathrm{H}]^{-}$(calcd for $\mathrm{C}_{17} \mathrm{H}_{16} \mathrm{O}_{5}, 299.0953$ ).

Busseihydroquinone $C$ (3): red, amorphous solid; $[\alpha]^{20}+0.9^{\circ}$ $(\mathrm{MeOH})$; UV $(\mathrm{MeOH}) \lambda_{\max } 305,245,210 \mathrm{~nm}$; IR (KBr) $\nu_{\max } 3550$, 3413, 3236, 1638, $1617 \mathrm{~cm}^{-1} ;{ }^{1} \mathrm{H}$ and ${ }^{13} \mathrm{C}$ NMR data see Table 1 ; HRESIMS $m / z 368.1418[\mathrm{M}-\mathrm{H}]^{-}\left(\right.$calcd for $\left.\mathrm{C}_{22} \mathrm{H}_{23} \mathrm{O}_{5}, 368.1460\right)$.

Busseihydroquinone $D(4)$ : orange, amorphous solid; $[\alpha]^{20}+0.9^{\circ}$ $(\mathrm{MeOH}) ; \mathrm{UV}(\mathrm{MeOH}) \lambda_{\max } 310,275,250 \mathrm{~nm}$; IR $(\mathrm{KBr}) \nu_{\max } 3550$, $3413,3236,1654,1638,1618,1522,1450,1400 \mathrm{~cm}^{-1}$; ${ }^{1} \mathrm{H}$ and ${ }^{13} \mathrm{C}$ NMR data see Table 1 ; HRESIMS $m / z 379.1182[\mathrm{M}-\mathrm{H}]^{-}$(calcd for $\mathrm{C}_{22} \mathrm{H}_{20} \mathrm{O}_{6}, 379.1176$ ).

Compound 5: yellow solid; $[\alpha]^{20}+0.6^{\circ}(\mathrm{MeOH}) ;{ }^{1} \mathrm{H}$ and ${ }^{13} \mathrm{C}$ NMR data see Table 1; HRESIMS $m / z 399.2020[\mathrm{M}+\mathrm{H}]^{+}$(calcd for $\mathrm{C}_{23} \mathrm{H}_{26} \mathrm{O}_{6} 399.1808$ ). The NMR and MS data are in agreement with the data given in ref 14 .

Antiplasmodial Assay. Two laboratory clones of Plasmodium falciparum, the Sierra Leone D6 chloroquine-sensitive and the Indochina W2 chloroquine-resistant, were maintained in continuous culture to attain replication robustness prior to assays. Drug susceptibility was tested by the malaria SYBR Green I-based in vitro assay technique. ${ }^{27}$ The reference antimalarial drugs chloroquine and mefloquine, having well-documented $\mathrm{IC}_{50}$ values, were tested along with test samples of naphthohydroquinones isolated from the roots of $P$. bussei as described above.

Cytotoxicity Assay. MCF-7 human breast cancer cells were cultured in Dulbecco's modified Eagle medium supplemented with $10 \%(\mathrm{v} / \mathrm{v})$ fetal bovine serum, $2 \mathrm{mM}$ L-glutamine, 100 units $/ \mathrm{mL}$ penicillin, and $100 \mu \mathrm{g} / \mathrm{mL}$ streptomycin at $37{ }^{\circ} \mathrm{C}$ in humidified $5 \%$ $\mathrm{CO}_{2}$. For cytotoxicity assays, cells were seeded in 96-well plates at optimal cell density to ensure exponential growth for the duration of the assay. After a $24 \mathrm{~h}$ preincubation, growth medium was replaced with experimental medium containing the appropriate drug concentrations or vehicle controls $(0.1 \%$ or $1.0 \% \mathrm{v} / \mathrm{v}$ DMSO). After $48 \mathrm{~h}$ incubation, cell viability was measured using PrestoBlue cell viability reagent (Invitrogen $\mathrm{AB}$, Lidingö, Sweden) according to the manufacturer's instructions. Absorbance was measured at $570 \mathrm{~nm}$ with $600 \mathrm{~nm}$ as a reference wavelength. Results were expressed as the mean \pm SE for six replicates as a percentage of vehicle control (taken as $100 \%)$. Experiments were performed independently at least three times. Statistical analyses were performed using a two-tailed Student's $t$ test. $p<0.05$ was considered to be statistically significant.

Antimicrobial Screening. The disk diffusion technique was applied. Initially $1 \mathrm{mg} / 1 \mathrm{~mL}$ stock solutions of the compounds were prepared for each compound, and $100 \mu \mathrm{L}$ was transferred onto sterile paper disks $(0.1 \mathrm{mg} /$ disk $)$ and allowed to dry. Microbial suspensions $(100 \mu \mathrm{L})$ were inoculated onto Petri dishes dispensed with appropriate media, and dry paper discs impregnated with the sample compounds were transferred onto these plates. This was performed in triplicates under sterile conditions, and the plates were incubated at $37^{\circ} \mathrm{C}$ for $E$. coli, Staph. aureus, and C. albicans and at $25{ }^{\circ} \mathrm{C}$ for A. niger. Two commercially used antibiotics, streptomycin for bacteria and nystatin for fungi, were used as standards at $0.1 \mathrm{mg} / 100 \mu \mathrm{L}$ concentration for comparison of the antimicrobial activities, while solvents used to prepare the samples were used as controls. The antimicrobial activity was determined after 24, 48, and $72 \mathrm{~h}$.

\section{ASSOCIATED CONTENT}

\section{S Supporting Information}

Original NMR and MS spectra of all compounds, HPLC chromatograms, confidence intervals for the cytotoxicity tests. This material is available free of charge via the Internet at http://pubs.acs.org.

\section{AUTHOR INFORMATION}

\section{Corresponding Author}

*Tel: +2542024446138. E-mail: ayenesew@uonbi.ac.ke. Tel: +46317869033. E-mail: mate@chem.gu.se.

\section{Funding}

We acknowledge the Swedish Research Council (VR20074407), International Science Program, Sweden (KEN-02), and the Swedish Institute $(210 / 00154 / 2010)$ as funding sources.

\section{Notes}

The authors declare no competing financial interest.

\section{ACKNOWLEDGMENTS}

We are grateful to F. L. Eyase (U.S. Army Medical Research Unit-Kenya, MRU 64109), M. Mbugua, A. Ndakala, and A. O. Yusuf (Dept. of Chemistry, University of Nairobi) for helpful advice. M. Endale is thankful to NAPRECA and to the Swedish Institute for financial support. J.P.A. and P.S. acknowledge the Chemical Biology Platform at the University of Gothenburg. M. Erdélyi acknowledges the support of the Swedish Research Council (VR2007-4407). A.Y. is thankful to the International Science Program, Sweden, for a research grant (KEN-02).

\section{REFERENCES}

(1) WHO. World Malaria Report, 2011.

(2) Willcox, M. L.; Bodeker, G. Br. Med. J. 2004, 329, 1156-1159.

(3) Tagboto, S.; Townson, S. Adv. Parasitol. 2001, 50, 199-295.

(4) Schlitzer, M. Pharm. Unserer Zeit 2009, 38, 522-526.

(5) Ginsburg, H.; Deharo, E. Malar. J. 2011, 10 Suppl 1, S1.

(6) Wells, T. N.; Alonso, P. L.; Gutteridge, W. E. Nat. Rev. Drug Discovery 2009, 8, 879-891.

(7) Claessens, S.; Verniest, G.; Jacobs, J.; Van Hende, E.; Habonimana, P.; Van, T. N.; Van Puyvelde, L.; De Kimpe, N. Synlett 2007, 829-850.

(8) Hari, L.; De Buyck, L. F.; De Pooter, H. L. Phytochemistry 1991, 30, 1726-1727.

(9) De Kimpe, N.; Van Puyvelde, L.; Schripsema, J.; Erkelens, C.; Verpoorte, R. Magn. Reson. Chem. 1993, 31, 329-330.

(10) Van Puyvelde, L.; Geysen, D.; Ayobangira, F. X.; Hakizamungu, E.; Nshimiyimana, A.; Kalisa, A. J. Ethnopharm. 1985, 13, 209-215.

(11) Endale, M.; Alao, J. P.; Akala, H. M.; Rono, N. K.; Eyase, F. L.; Derese, S.; Ndakala, A.; Mbugua, M.; Walsh, D. S.; Sunnerhagen, P.; Erdelyi, M.; Yenesew, A. Planta Med. 2012, 78, 31-35.

(12) Muthaura, C. N.; Rukunga, G. M.; Chhabra, S. C.; Mungai, G. M.; Njagi, E. N. J. Ethnopharm. 2007, 114, 377-386.

(13) Irungu, B. N.; Rukunga, G. M.; Mungai, G. M.; Muthaura, C. N. S. Afr. J. Bot. 2007, 73, 204-207.

(14) Bukuru, J. F.; Van, T. N.; Van Puyvelde, L.; Mathenge, S. G.; Mudida, F. P.; De Kimpe, N. J. Nat. Prod. 2002, 65, 783-785. 
(15) Bukuru, J.; Van, T. N.; Van Puyvelde, L.; He, W. D.; De Kimpe, N. Tetrahedron 2003, 59, 5905-5908.

(16) Panichpol, K.; Waterman, P. G. Phytochemistry 1978, 17, 13631367.

(17) Claessens, S.; Kesteleyn, B.; Van, T. N.; De Kimpe, N. Tetrahedron 2006, 62, 8419-8424.

(18) El-Hady, S.; Bukuru, J.; Kesteleyn, B.; Van Puyvelde, L.; Van, T. N.; De Kimpe, N. J. Nat. Prod. 2002, 65, 1377-1379.

(19) Sastry, M. N.; Claessens, S.; Habonimana, P.; De Kimpe, N. J. Org. Chem. 2010, 75, 2274-2280.

(20) Mudiganti, N. V. S.; Claessens, S.; De Kimpe, N. Tetrahedron Lett. 2008, 49, 6980-6983.

(21) Mudiganti, N. V. S.; Claessens, S.; Habonimana, P.; De Kimpe, N. J. Org. Chem. 2008, 73, 3867-3874.

(22) Kokwaro, J. O. Medicinal Plants of East Africa; University of Nairobi Press: Nairobi, 2010; pp 247-248.

(23) Wokaun, A.; Ernst, R. R. Chem. Phys. Lett. 1977, 52, 407-412.

(24) Kumar, A.; Ernst, R. R.; Wuthrich, K. Biochem. Biophys. Res. Commun. 1980, 95, 1-6.

(25) Perpickdumont, M.; Reynolds, W. F.; Enriquez, R. G. Magn. Reson. Chem. 1988, 26, 358-361.

(26) Parella, T. Magn. Reson. Chem. 1998, 36, 467-495.

(27) Juma, W. P.; Akala, H. M.; Eyase, F. L.; Muiva, L. M.; Heydenreich, M.; Okalebo, F. A.; Gitu, P. M.; Peter, M. G.; Walsh, D. S.; Imbuga, M.; Yenesew, A. Phytochem. Lett. 2011, 4, 176-178. 